\title{
Insulin resistance and endometrial cancer risk: A systematic review and meta-analysis
}

ARTICLE in EUROPEAN JOURNAL OF CANCER · DECEMBER 2015

Impact Factor: 5.42 · DOI: 10.1016/j.ejca.2015.08.031

READS

46

6 AUTHORS, INCLUDING:

Adrian V Hernandez

Cleveland Clinic

182 PUBLICATIONS 3,036 CITATIONS

SEE PROFILE

Vicente Aleixandre Benites-Zapata National Institute of Health of Peru 32 PUBLICATIONS 3 CITATIONS

SEE PROFILE
Vinay Pasupuleti

Case Western Reserve University

60 PUBLICATIONS 485 CITATIONS

SEE PROFILE

Abhishek Deshpande

Cleveland Clinic

101 PUBLICATIONS 661 CITATIONS

SEE PROFILE 


\title{
Review
}

\section{Insulin resistance and endometrial cancer risk: A systematic review and meta-analysis}

\author{
Adrian V. Hernandez ${ }^{\mathrm{a}, \mathrm{b}, *, 1}$, Vinay Pasupuleti ${ }^{\mathrm{c}, 1}$, \\ Vicente A. Benites-Zapata ${ }^{d}$, Priyaleela Thota ${ }^{c}$, Abhishek Deshpande ${ }^{\mathrm{e}}$, \\ Faustino R. Perez-Lopez ${ }^{\mathrm{f}}$
}

\footnotetext{
${ }^{a}$ School of Medicine, Universidad Peruana de Ciencias Aplicadas (UPC), Lima 9, Peru

${ }^{\mathrm{b}}$ Health Outcomes and Clinical Epidemiology Section, Department of Quantitative Health Sciences, Cleveland Clinic, Cleveland, OH, 44195 USA

${ }^{\mathrm{c}}$ Department of Medicine, Case Western Reserve University, Cleveland, OH, 44106 USA

${ }^{\mathrm{d}}$ Faculty of Human Medicine, Postgraduate Section, Universidad de San Martin de Porres, Lima 12, Peru

${ }^{\mathrm{e}}$ Medicine Institute Center for Value Based Care Research, Cleveland Clinic, Cleveland, OH, 44195 USA

${ }^{\mathrm{f}}$ Department of Obstetrics and Gynecology, University of Zaragoza Faculty of Medicine and Lozano Blesa University

Hospital, Domingo Miral s/n, Zaragoza 50009, Spain
}

Received 22 June 2015; received in revised form 24 August 2015; accepted 30 August 2015

\section{KEYWORDS}

Insulin resistance;

Endometrial cancer;

Meta-analysis

\begin{abstract}
Aim: It has been suggested that chronic hyperinsulinemia from insulin resistance is involved in the etiology of endometrial cancer (EC). We performed a systematic review and meta-analysis to assess whether insulin resistance is associated with the risk of EC.

Methods: We searched PubMed-Medline, Embase, Scopus, and Web of Science for articles published from database inception through 30th September 2014. We included all observational studies evaluating components defining insulin resistance in women with and without EC. Quality of the included studies was assessed by Newcastle-Ottawa scale. Randomeffects models and inverse variance method were used to meta-analyze the association between insulin resistance components and EC.

Results: Twenty-five studies satisfied our inclusion criteria. Fasting insulin levels (13 studies, $n=4088$ ) were higher in women with EC (mean difference [MD] 33.94 pmol/L, $95 \%$ confidence interval [CI] 15.04-52.85, $p=0.0004)$. No differences were seen in postmenopausal versus pre- and postmenopausal subgroup analysis. Similarly, non-fasting/fasting C-peptide levels (five studies, $n=1938$ ) were also higher in women with EC (MD $0.14 \mathrm{nmol} / \mathrm{L}, 95 \%$
\end{abstract}

\footnotetext{
* Corresponding author: Research Center, School of Medicine, Universidad Peruana de Ciencias Aplicadas (UPC), Building F, Campus Villa, Avenida Alameda de San Marcos Cuadra 2 s/n, Chorrillos, Lima 9, Peru. Tel.: +51 $13133333 \times 2730$.

E-mail addresses: adrianhernandezdiaz@gmail.com(A.V.Hernandez), lepiscean@gmail.com (V.Pasupuleti),vbeniteszapata@gmail. com (V.A.Benites-Zapata),tpriyaleela@gmail.com (P.Thota), abhishekdp@gmail.com (A. Deshpande), faustino.perez@unizar.es (F.R. Perez-Lopez).

${ }^{1}$ Contributed equally to the study.
} 
CI $0.08-0.21, p<0.00001)$. Homeostatic model assessment - insulin resistance (HOMA-IR) values (six studies, $n=1859$ ) in EC patients were significantly higher than in women without EC (MD 1.13, 95\% CI 0.20-2.06, $p=0.02$ ). There was moderate-to-high heterogeneity among the included studies.

Conclusion: Currently available epidemiologic evidence is suggestive of significantly higher risk of EC in women with high fasting insulin, non-fasting/fasting C-peptide and HOMAIR values.

(C) 2015 Elsevier Ltd. All rights reserved.

\section{Introduction}

Endometrial cancer (EC) is the most common female genital malignancy in developed countries, and its incidence is growing worldwide due to increases in both life expectancy and obesity prevalence. Its pathogenesis still remains poorly understood although the prevailing hypothesis is that a dominant oestrogenic environment favours EC development [1,2], and some gene variants for enzymes in sex-steroid synthesis pathways could also contribute to the hyperoestrogenic status associated with the risk of EC [3,4]. Oral contraceptives confer long-term protection against EC [5], while long-term sequential oestrogen plus progestogen use in menopause is known to increase the EC risk, and continuous combined oestrogen + progestogen therapy in menopause is known to reduce EC risk [6]. EC is substantially more frequent with extended adjuvant tamoxifen treatment while fertility drug treatments do not increase the EC risk [7,8].

Numerous epidemiological studies confirm an association between obesity and various cancer forms, including EC [9]. This malignancy has also been associated with sedentarism, type II diabetes mellitus, and polycystic ovary syndrome [10-14]. In postmenopausal women, excessive body weight and EC risk may be associated with an increased synthesis of oestrogen, insulin resistance, and inflammation [15-17]. Insulin resistance is highly prevalent among EC patients, including non-obese women [18], and hyperinsulinemia has been postulated as an EC risk factor independent of estradiol [19]. On the other hand, the insulin-sensitiser metformin decreases EC proliferation, may induce apoptosis and has positive effects on cancer clinical evolution $[20]$. However, the relationship between insulin resistance and EC development is poorly understood. We evaluated in a systematic review the current evidence on the effects of insulin resistance on the risk of EC and their potential translational clinical applications are also discussed.

\section{Materials and methods}

\subsection{Data sources and searches}

A comprehensive literature search was performed using PubMed-Medline, Embase, Web of Science and Scopus from database inception through 30th September 2014. The database searches were performed independently by two authors (VP and VAB-Z). The PubMed search strategy is available as Supplementary data.

The following pre-determined inclusion criteria were used: (i) observational studies evaluating the association between insulin resistance and EC, (ii) study population of patients $>18$ years, and (iii) study in any language. Our exclusion criteria were as follows: (i) no control group and (ii) fasting insulin, non-fasting/fasting Cpeptide or homeostatic model assessment - insulin resistance (HOMA-IR) data were not available or could not be extracted for each of the study groups [21]. Controls are defined as patients without EC. Four study authors were contacted with requests for missing information. Only one study author responded with the requested data.

\subsection{Study selection and data extraction}

A list of retrieved articles were reviewed independently by two investigators (VP and VAB-Z) to choose potentially relevant articles, and disagreements on inclusion/exclusion were discussed and resolved by consensus. Two reviewers (VP and VAB-Z) independently extracted data from included studies. The following information was extracted: age, body mass index (BMI), menopausal status, insulin and/or C-peptide levels, method of diagnosis of EC, fasting status when blood samples were collected, and assays for quantifying insulin and C-peptide. Information on HOMA-IR (glucose $\times$ insulin/a normalising constant) scores was also collected, whenever available. One author $(\mathrm{AVH})$ reviewed the extractions for inconsistencies, and three authors (VP, VAB-Z and AVH) reached consensus.

\subsection{Evaluation of study quality}

The quality of the selected studies was assessed independently by two authors (VP and VAB-Z) using the Newcastle-Ottawa scale (NOS) [22]. The NOS uses two different tools for case-control and cohort studies and consists of three parameters of quality: selection, comparability and exposure/outcome assessment. The 
NOS assigns a maximum of four points for selection, two points for comparability and three points for exposure or outcome. NOS scores of $\geq 7$ were considered as high-quality studies and of 5-6 as moderate quality. An adapted form of the cohort NOS was used for assessing risk of bias in cross-sectional studies [23]. All discrepancies were addressed by a re-evaluation of the original article as a group (VP, VAB-Z and AVH).

\subsection{Data synthesis and analysis}

Our systematic review and meta-analysis follow the recommendations of the Preferred Reporting Items for Systematic Reviews and Meta-Analyses collaboration [24]. DerSimonian and Laird random-effects models and inverse variance method were used for all meta-analyses [25].

As the studies provided means of continuous outcomes, we used the mean difference (MD) to calculate summary statistics. We evaluated statistical heterogeneity using the tau-squared $\left(\mathrm{Tau}^{2}\right)$, Cochran chi-square $\left(\chi^{2}\right)$ and the $I^{2}$ statistic $[26,27] . I^{2}$ values of $40-60 \%$ represented a moderate level of heterogeneity. A $p$ value of $<0.1$ for $\chi^{2}$ was defined as indicating the presence of heterogeneity. $\mathrm{Tau}^{2}$ provides an estimate of betweenstudy variance in random-effects meta-analysis; a $\mathrm{Tau}^{2}$ of $>1$ suggests the presence of substantial statistical heterogeneity. Publication bias was explored with the funnel plot and tested with the Egger test of funnel plot asymmetry [28]. When the median and interquartile range (IQR) were provided, the mean was estimated by the formula $x=(a+2 m+b) / 4$ using the values of the median (m), P25 and P75 ( $a$ and $b$, respectively) and the standard deviation (SD) was estimated using $\mathrm{SD}=\mathrm{IQR} / 1.35[29]$. When the median and range were provided, the mean was estimated by the formula $x=(a+2 m+b) / 4$ using the values of the median $(m)$, the smallest value, and the largest value (a and $b$, respectively) and the SD was estimated by the formula $\mathrm{SD}=$ range $/ 4$ if the sample size was $<70$ and $\mathrm{SD}=$ range/6 if the sample size was $>70$ [30]. Insulin values were expressed as SI units (1 $\mu \mathrm{IU} /$ $\mathrm{ml}=6.945 \mathrm{pmol} / \mathrm{L}) \quad[31]$. C-peptide values were expressed as SI units $(1 \mathrm{ng} / \mathrm{ml}=0.333 \mathrm{nmol} / \mathrm{L})[32]$. We performed pre-specified subgroup analyses by study quality and by menopausal status (postmenopausal only versus pre- and postmenopausal). We used Review Manager (RevMan, version 5.0 for Windows; The Cochrane Collaboration, Oxford, UK) [33] and STATA 12 (College Station, TX, USA) for statistical analyses.

\section{Results}

\subsection{Eligible studies}

Our search identified 1903 publications (Fig. 1). After removing duplicates, 1019 articles were screened by study titles/abstracts for relevance to study topic and inclusion/exclusion criteria. Forty-three articles remained for full-text review (Fig. 1). Twenty-five studies that reported levels of components that define insulin resistance and their association with EC in women were included in the meta-analysis $[15,19$, 34-56]. The reasons for exclusion of the remaining 18 articles are listed in Fig. 1.

\subsection{Study characteristics}

Table 1 summarises the main characteristics of the included studies. Of the 25 studies $(n=33,792)$ included, 2 were prospective cohort studies [34-35], 21 case-control studies [15,19,36-54], and 2 cross-sectional studies $[55,56]$. Sample size in these studies ranged from 20 to 24,644 . EC cases in the studies ranged from $1.4 \%$ to $74.1 \%$. EC cases were identified by histopathology records in 17 studies, cancer/pathology registries in 2 , and histopathology or cytology in 1, and no information was provided in 5. Study population included postmenopausal women only in 11 studies and both pre- and postmenopausal women in 14 .

\subsection{Quality assessment and publication bias}

Using the NOS scale, all but four studies were identified as high quality (Supplementary Table 1) $[39,45,49,54]$. The funnel plot did not suggest the presence of publication bias (Supplementary Fig. 1). The formal test of asymmetry of this plot was not significant with Egger $p$ value of $0.9,0.3$ and 0.5 for studies providing information on fasting insulin, C-peptide and HOMA-IR, respectively.

\subsection{Meta-analyses}

Fasting insulin levels (13 studies, $n=4088$ ) were significantly higher in women with EC compared to women without EC (MD $33.94 \mathrm{pmol} / \mathrm{L}, 95 \%$ confidence interval $[\mathrm{CI}] 15.04-52.85, p=0.0004, I^{2}=100 \%$ ) (Fig. 2). Non-fasting/fasting C-peptide levels (five studies, $n=1938$ ) were significantly higher in women with EC (MD $0.14 \mathrm{nmol} / \mathrm{L}, 95 \%$ CI $0.08-0.21$, $p<0.00001, I^{2}=42 \%$ ) (Fig. 3). High HOMA-IR levels (six studies, $n=1859$ ) were also significantly associated with women with EC (MD 1.13, 95\% CI 0.20-2.06, $p=0.02, I^{2}=94 \%$ ) (Fig. 4). There was moderate-tohigh heterogeneity for these associations.

\subsection{Subgroup analyses}

Differences in fasting insulin levels between EC and controls were larger in case-control studies than in other study designs; this difference did not reach statistical significance ( $p=0.06$ ) (Fig. 2). Also, differences in fasting insulin levels between EC and controls were 


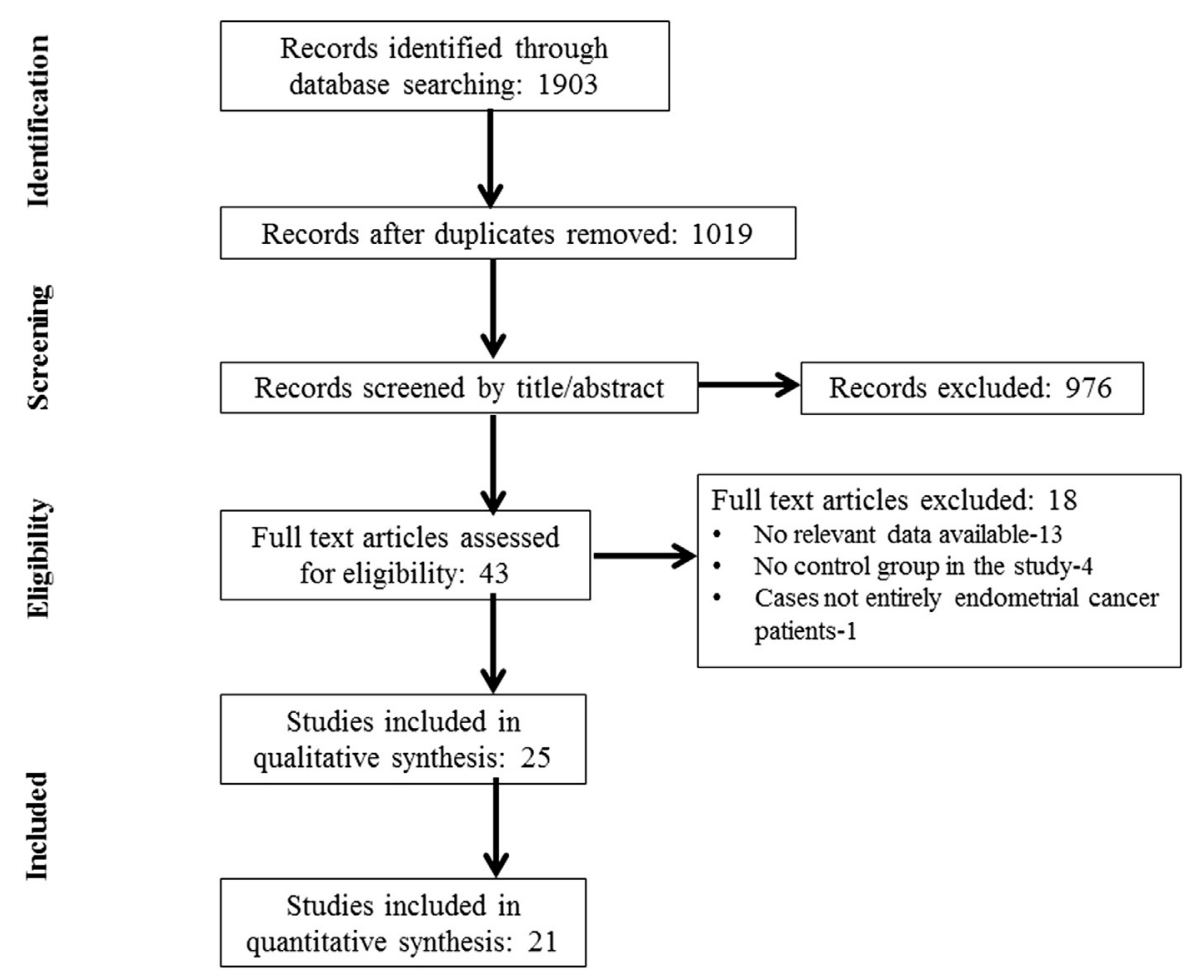

Fig. 1. Flow diagram of included studies.

larger in studies including both pre- and postmenopausal women than in those only including postmenopausal women $(p=0.29$ for differences between subgroups); heterogeneity remained high $\left(I^{2}=90 \%\right)$ (Supplementary Fig. 2). Finally, high-quality studies had a smaller difference in fasting insulin levels than moderate-quality studies ( $p=0.31$ for differences between subgroups); heterogeneity remained high $\left(I^{2}=100 \%\right)$ (Supplementary Fig. 3).

\section{Discussion}

This is the first systematic review and meta-analysis to assess the role of insulin resistance in women with EC. Our meta-analysis demonstrated that there are significantly higher circulating fasting insulin and fasting/nonfasting C-peptide levels as well higher HOMA-IR values in women with EC. Available studies were heterogeneous with respect to study design, other study characteristics and the extent of the association between components of insulin resistance and EC. Our findings are in concurrence with experimental studies demonstrating the involvement of insulin in the development of malignant endometrial histological features and anchorage-independent growth [57]. A recent metaanalysis of six studies reported a significant increased risk of EC in women with metabolic syndrome (relative risk: $1.89,95 \%$ CI 1.34-2.67) [58]. However, metabolic syndrome does not include a direct insulin estimate. In addition, during the last decade, the clinical definition of metabolic syndrome has had vast discrepancies in the diagnosis definitions and its prevalence. Elevated circulating insulin levels have been correlated with disordered proliferative endometrium, endometrial hyperplasia and EC, and the risk increased when the HOMA-IR is $\geq 2.95$ [56]. Our meta-analysis of 13 studies demonstrated that patients diagnosed with EC have a significantly higher mean insulin difference of $33.94 \mathrm{pmol} / \mathrm{L}$ as compared to women without the malignancy. Hyperinsulinism is a marker of insulin resistance and alters metabolic cell functions which consequently trigger several biochemical changes [59]. It is likely that effects of insulin resistance are more pronounced in inducing endometrial carcinogenesis in postmenopausal women, in presence of lower levels of ovarian hormones and when other metabolic factors may contribute to carcinogenesis. In fact, the prevalence of EC is higher in postmenopausal women than in women during reproductive years. However, we did not find a higher association between insulin resistance and EC in the subgroup of studies including only postmenopausal women in comparison with those studies including both pre- and postmenopausal women. This may be due to the scarcity of studies and the small numbers of women with EC in studies. Hyperinsulinism is central to pathways involving several factors including genetics, diet, body mass and obesity, inflammation, physical activity and others; a few of these have bidirectional (mutual) influences $[1,2,59]$.

In our meta-analysis of five observational studies, we demonstrate that patients with EC have significantly higher C-peptide values as compared to women without 
Table 1

Basic characteristics of included studies.

\begin{tabular}{|c|c|c|c|c|c|c|c|c|c|c|c|}
\hline $\begin{array}{l}\text { First author, } \\
\text { year published }\end{array}$ & $\begin{array}{l}\text { Study } \\
\text { location }\end{array}$ & $\begin{array}{l}\text { Study } \\
\text { design }\end{array}$ & Study population & $\begin{array}{l}\text { Sample } \\
\text { size }\end{array}$ & $\begin{array}{l}\text { EC cases } \\
(\%)\end{array}$ & $\begin{array}{l}\text { Age, } \\
\text { mean (SD) }\end{array}$ & $\begin{array}{l}\text { Blood } \\
\text { samples }\end{array}$ & Biochemical assay & EC diagnosis & $\begin{array}{l}\text { Insulin resistance } \\
\text { definition }\end{array}$ & $\begin{array}{l}\text { Matched or adjusted } \\
\text { confounders }\end{array}$ \\
\hline $\begin{array}{l}\text { Lucas WE, } \\
1979 \text { [34] }\end{array}$ & USA & $\mathrm{PC}$ & Postmenopausal & 32 & 50.0 & $57.7(1.9)$ & Fasting & RIA & Histopathology & NR & $\begin{array}{l}\text { Matched for age } \\
\text { and weight }\end{array}$ \\
\hline $\begin{array}{c}\text { Nagamani M, } \\
1988[37]\end{array}$ & USA & $\mathrm{CC}$ & Postmenopausal & 20 & 50.0 & 61.0 & Fasting & RIA & Histopathology & NR & $\begin{array}{l}\text { Matched for age, } \\
\text { weight and years } \\
\text { since menopause }\end{array}$ \\
\hline $\begin{array}{c}\text { Rutanen EM, } \\
1993 \text { [38] }\end{array}$ & $\begin{array}{l}\text { Finland, } \\
\text { Germany }\end{array}$ & $\mathrm{CC}$ & Postmenopausal & 50 & 64.0 & 65.4 & Fasting & RIA & Histopathology & NR & $\begin{array}{l}\text { Matched for } \\
\text { age, BMI and } \\
\text { postmenopausal } \\
\text { years }\end{array}$ \\
\hline $\begin{array}{l}\text { Gamayunova } \\
\text { VB, } 1997 \text { [39] }\end{array}$ & Russia & $\mathrm{CC}$ & $\begin{array}{l}\text { Pre- and } \\
\text { postmenopausal }\end{array}$ & 53 & 34.0 & $53.4(5.3)$ & Fasting & RIA & NR & NR & None \\
\hline $\begin{array}{l}\text { Troisi R, } \\
\quad 1997[40]\end{array}$ & USA & $\mathrm{CC}$ & $\begin{array}{l}\text { Pre- and } \\
\text { postmenopausal }\end{array}$ & 345 & 47.8 & 62.4 & Fasting & RIA & Histopathology & NR & $\begin{array}{l}\text { Matched for age, } \\
\text { race and zip code; } \\
\text { adjusted for age, } \\
\text { BMI and WTR }\end{array}$ \\
\hline $\begin{array}{c}\text { Anderson KE, } \\
2001[35]\end{array}$ & USA & $\mathrm{PC}$ & Postmenopausal & 24,664 & 1.4 & 61.8 & NR & NR & Histopathology & NR & $\begin{array}{l}\text { Adjusted for age, } \\
\text { WHR, ovulatory } \\
\text { span, gravidity, } \\
\text { HRT use, HTN } \\
\text { and menstrual } \\
\text { irregularities }\end{array}$ \\
\hline $\begin{array}{c}\text { Waksmanski B, } \\
2001[41]\end{array}$ & Poland & $\mathrm{CC}$ & $\begin{array}{l}\text { Pre- and } \\
\text { postmenopausal }\end{array}$ & 48 & 50.0 & NR & Fasting & RIA & Histopathology & NR & $\begin{array}{l}\text { Matched for } \\
\text { age and BMI }\end{array}$ \\
\hline $\begin{array}{l}\text { Weiderpass E, } \\
2003[42]\end{array}$ & Sweden & $\mathrm{CC}$ & Postmenopausal & 680 & 42.4 & $63.7(7.1)$ & Fasting & RIA & Histopathology & NR & $\begin{array}{l}\text { Matched for age } \\
\text { groups, geography } \\
\text { and season; adjusted } \\
\text { for age, BMI, diabetes } \\
\text { mellitus, physical } \\
\text { activity, menopausal } \\
\text { status, HRT and } \\
\text { OCP use }\end{array}$ \\
\hline $\begin{array}{l}\text { Lukanova A, } \\
2004[43]\end{array}$ & $\begin{array}{l}\text { USA, Sweden, } \\
\text { Italy }\end{array}$ & $\mathrm{CC}$ & $\begin{array}{l}\text { Pre- and } \\
\text { postmenopausal }\end{array}$ & 481 & 34.5 & NR & $\begin{array}{l}\text { Fasting and } \\
\text { non-fasting }\end{array}$ & RIA & Histopathology & NR & $\begin{array}{l}\text { Matched for age, } \\
\text { recruitment date } \\
\text { and menopausal } \\
\text { status; adjusted for } \\
\text { BMI, parity, fasting } \\
\text { status at sampling, } \\
\text { HRT and OCP use }\end{array}$ \\
\hline $\begin{array}{l}\text { Cust AE, } \\
\quad 2007[44]\end{array}$ & $\begin{array}{l}\text { Denmark, Italy, } \\
\text { UK, Spain, The } \\
\text { Netherlands, } \\
\text { Germany, France, } \\
\text { Greece }\end{array}$ & $\mathrm{CC}$ & $\begin{array}{l}\text { Pre- and } \\
\text { postmenopausal }\end{array}$ & 841 & 34.0 & 56.9 & $\begin{array}{l}\text { Fasting and } \\
\text { non-fasting }\end{array}$ & IRMA & Histopathology & NR & $\begin{array}{l}\text { Matched for study } \\
\text { centre, menopausal } \\
\text { status, age and time } \\
\text { of the day at blood } \\
\text { collection, fasting status } \\
\text { (continued on next page) }\end{array}$ \\
\hline
\end{tabular}




\begin{tabular}{|c|c|c|c|c|c|c|c|c|c|c|c|}
\hline $\begin{array}{l}\text { First author, } \\
\text { year published }\end{array}$ & $\begin{array}{l}\text { Study } \\
\text { location }\end{array}$ & $\begin{array}{l}\text { Study } \\
\text { design }\end{array}$ & Study population & $\begin{array}{l}\text { Sample } \\
\text { size }\end{array}$ & $\begin{array}{l}\text { EC cases } \\
(\%)\end{array}$ & $\begin{array}{l}\text { Age, } \\
\text { mean (SD) }\end{array}$ & $\begin{array}{l}\text { Blood } \\
\text { samples }\end{array}$ & Biochemical assay & EC diagnosis & $\begin{array}{l}\text { Insulin resistance } \\
\text { definition }\end{array}$ & $\begin{array}{l}\text { Matched or adjusted } \\
\text { confounders }\end{array}$ \\
\hline $\begin{array}{l}\text { Gunter MJ, } \\
2008[19]\end{array}$ & USA & $\mathrm{CC}$ & Postmenopausal & 715 & 33.6 & $62.9(7.3)$ & Fasting & NR & Histopathology & $\begin{array}{l}\text { HOMA-IR }=\text { FINS } \\
(\mu \mathrm{U} / \mathrm{L}) \times \text { FBG } \\
(\mathrm{mmol} / \mathrm{L}) / 22.5\end{array}$ & $\begin{array}{l}\text { Adjusted for age, } \\
\text { BMI, estradiol, } \\
\text { HRT use and } \\
\text { free IGF-I }\end{array}$ \\
\hline $\begin{array}{l}\text { Hua SF, } \\
\quad 2008[45]\end{array}$ & China & $\mathrm{CC}$ & $\begin{array}{l}\text { Pre- and } \\
\text { postmenopausal }\end{array}$ & 85 & 74.1 & $52.0(10.0)$ & Fasting & NR & NR & NR & None \\
\hline $\begin{array}{l}\text { Friedenreich } \\
\quad \text { CM, } 2011 \text { [46] }\end{array}$ & Canada & $\mathrm{CC}$ & $\begin{array}{l}\text { Pre- and } \\
\text { postmenopausal }\end{array}$ & 1477 & 34.9 & $58.5(9.9)$ & Fasting & ELISA & Histopathology & NR & $\begin{array}{l}\text { Matched for age; } \\
\text { adjusted for parity, } \\
\text { HRT use, weight, } \\
\text { WHR, HTN, glucose, } \\
\text { leptin, adiponectin }\end{array}$ \\
\hline Wang T, 2011 [15] & USA & $\mathrm{CC}$ & Postmenopausal & 452 & 33.4 & $64.1(7.4)$ & Fasting & NR & Histopathology & NR & None \\
\hline $\begin{array}{l}\text { Friedenreich } \\
\qquad \text { CM, } 2012 \text { [47] }\end{array}$ & Canada & $\mathrm{CC}$ & $\begin{array}{l}\text { Pre- and } \\
\text { postmenopausal }\end{array}$ & 1475 & 34.9 & 59.0 & Fasting & RIA & Histopathology & NR & $\begin{array}{l}\text { Matched for age; } \\
\text { adjusted for parity, } \\
\text { HRT use, weight, } \\
\text { WHR, HTN, } \\
\text { glucose, leptin, } \\
\text { adiponectin }\end{array}$ \\
\hline $\begin{array}{l}\text { Modesitt } \\
\quad \text { SC, } 2012 \text { [48] }\end{array}$ & USA & $\mathrm{CC}$ & Postmenopausal & 38 & 57.8 & 58.3 & Fasting & ELISA & NR & NR & None \\
\hline Fu JR, 2012 [49] & China & $\mathrm{CC}$ & $\begin{array}{l}\text { Pre- and } \\
\text { postmenopausal }\end{array}$ & 65 & 53.9 & $32-71^{*}$ & Fasting & $\begin{array}{l}\text { ELISA, RIA, } \\
\text { electro- } \\
\text { chemilluminometry }\end{array}$ & NR & NR & None \\
\hline $\begin{array}{l}\text { Dallal } \\
\qquad \mathrm{CM}, 2013 \text { [50] }\end{array}$ & USA & $\mathrm{CC}$ & Postmenopausal & 186 & 33.3 & $67.4(5.2)$ & Fasting & ELISA & Cancer registry & NR & $\begin{array}{l}\text { Matched for study } \\
\text { site, age and time } \\
\text { at blood draw }\end{array}$ \\
\hline $\begin{array}{l}\text { Dossus L, } \\
\quad 2013[36]\end{array}$ & $\begin{array}{l}\text { Denmark, } \\
\text { Italy, UK, } \\
\text { Spain, The } \\
\text { Netherlands, } \\
\text { Germany, } \\
\text { France, Greece, } \\
\text { Sweden }\end{array}$ & $\mathrm{CC}$ & $\begin{array}{l}\text { Pre- and } \\
\text { postmenopausal }\end{array}$ & 679 & 34.3 & $57.7(7.2)$ & Fasting & IRMA & $\begin{array}{l}\text { Pathology } \\
\text { registries }\end{array}$ & NR & $\begin{array}{l}\text { Matched for study } \\
\text { centre, menopausal } \\
\text { status, fasting status, } \\
\text { age at enrollment } \\
\text { and time of day } \\
\text { of blood collection }\end{array}$ \\
\hline $\begin{array}{l}\text { Erdogan S, } \\
2013[55]\end{array}$ & Turkey & $\mathrm{CS}$ & Postmenopausal & 130 & 46.2 & $52.9(8.9)$ & Fasting & $\begin{array}{l}\text { Chemiluminescent } \\
\text { microparticle } \\
\text { immunoassay }\end{array}$ & $\begin{array}{l}\text { Histopathology, } \\
\text { cytology }\end{array}$ & $\begin{array}{l}\text { HOMA-IR }=\text { FINS } \\
(\mu \mathrm{U} / \mathrm{L}) \times \text { FBG } \\
(\mathrm{mmol} / \mathrm{L}) / 22.5\end{array}$ & None \\
\hline $\begin{array}{l}\text { Ma Y, } \\
\quad 2013[51]\end{array}$ & China & $\mathrm{CC}$ & $\begin{array}{l}\text { Pre- and } \\
\text { postmenopausal }\end{array}$ & 516 & 39.9 & 53.3 & Fasting & $\begin{array}{l}\text { Chemiluminescent } \\
\text { immunoassay }\end{array}$ & Histopathology & NR & Matched for age \\
\hline $\begin{array}{l}\text { Zhan Y, } \\
\quad 2013 \text { [52] }\end{array}$ & China & $\mathrm{CC}$ & $\begin{array}{l}\text { Pre- and } \\
\text { postmenopausal }\end{array}$ & 556 & 37.1 & $53.4(10.0)$ & Fasting & $\begin{array}{l}\text { Chemiluminescent } \\
\text { immunoassay }\end{array}$ & Histopathology & NR & $\begin{array}{l}\text { Adjusted for age, } \\
\text { glucose, BMI, TC, } \\
\text { TG, HDL-C } \\
\text { and IGFBP }\end{array}$ \\
\hline
\end{tabular}




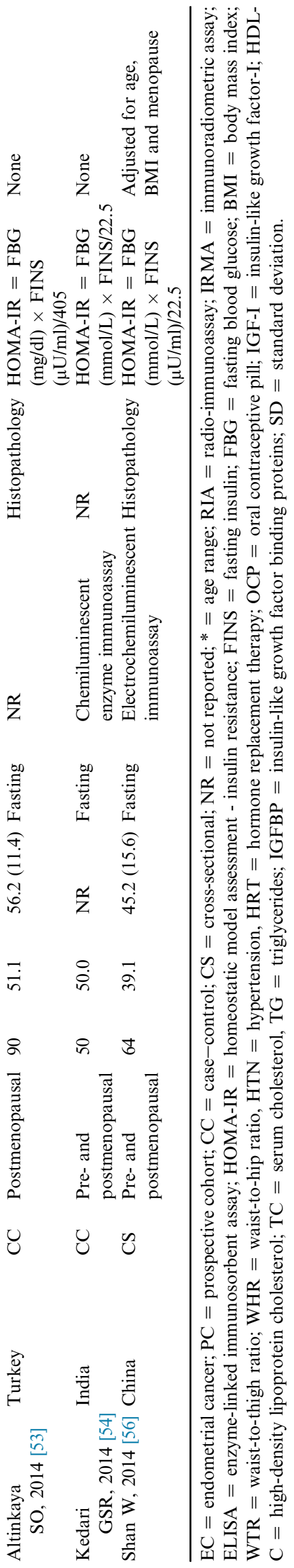

the malignancy. The lack of information on fasting time since the last meal may have led to misclassification of $\mathrm{C}$-peptide levels based on fasting status and could have biased data towards the null. Higher C-peptide levels derived from insulin resistance is known to elevate the risk of non-genital cancers [60]. Proinsulin C-peptide links the A- and B-chains of insulin and facilitates different intracellular insulin synthesis steps by pancreatic $\beta$-cells. C-peptide and insulin are intracellularly stored and both released into the portal circulation in equimolar amounts. Higher C-peptide levels are observed in overweight subjects and, unlike insulin, Cpeptide is not metabolised by the liver but is catabolised by the kidneys [61]. It has a longer half-life than insulin itself, reflecting more precisely the individual levels of circulating insulin when sampling has not been systematically performed in fasting conditions although blood levels are also under the influences of hepatic blood flow and extraction and BMI $[62,63]$. Thus, C-peptide can be considered as an indirect marker of insulin secretion. The current meta-analysis confirms and reinforces the idea that insulin resistance is associated with the EC risk.

A wide range of surrogate insulin resistance and sensitivity measures or indices have been correlated with hyperinsulinemic-euglycemic clamp, the gold standard method to assess insulin sensitivity. The glycemic load and the glycemic index influence insulin secretion and insulin-growth factors. In our meta-analysis, glucose metabolism was assessed using the HOMA-IR which estimates insulin resistance and is one of the most popular algorithms incorporating both glucose and insulin blood measurements [21]. We anticipated that HOMA-IR values might be more strongly associated with EC than individual insulin or C-peptide concentrations. This was ascertained in our pooled analysis of data from six studies which showed an MD of 1.13 HOMA-IR units, between patients with EC and women without the malignancy. Other mathematical models or indices, such as the quantitative insulin sensitivity index (QUICKI) or the Matsuda index, have been proposed as alternatives to the standard clamp and HOMA-IR studies [64]. The QUICKI is the inverse of the HOMA-IR (QUICKI $=1 /(\log ($ fasting insulin) in $\mu \mathrm{U} /$ $\mathrm{ml}+\log ($ fasting glucose) in $\mathrm{mg} / \mathrm{dl})$ and assesses insulin sensitivity instead of insulin resistance. Abnormal QUICKI values $(<0.357)$ have been reported in one small series of patients with EC, which was included in our meta-analysis [18]. The Matsuda index and other surrogate tests use information derived from dynamic tests after glucose or meal tolerance, but have not been reported in studies included in our systematic review.

Our study has limitations. EC is a heterogeneous disease that traditionally included two prototypes (type I and type II) based on histopathological characteristics and clinical severity, although genomic studies suggest relevant subsets of the disease [65]. We were unable to 


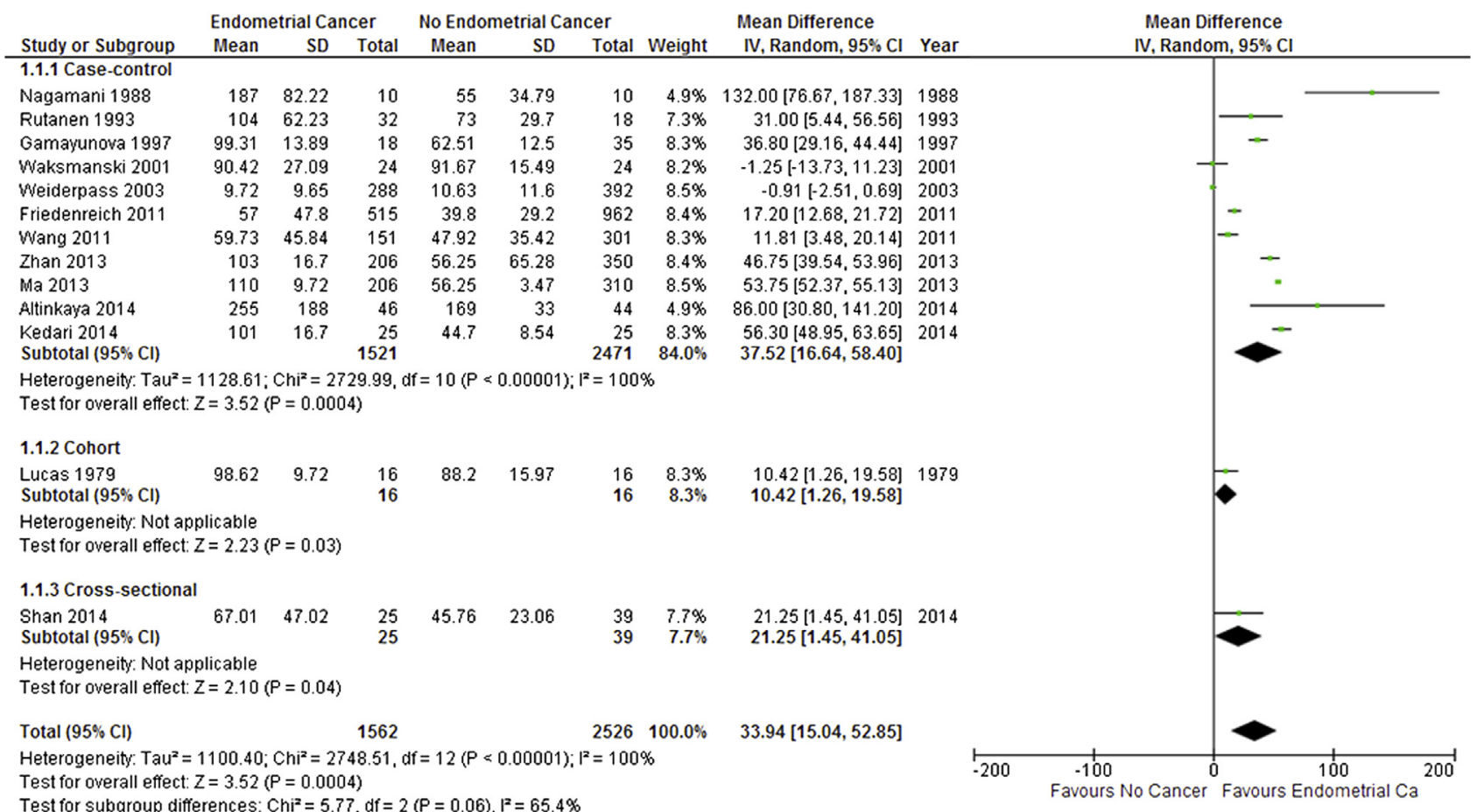

Fig. 2. Forest plot of the association between fasting insulin levels and endometrial cancer.

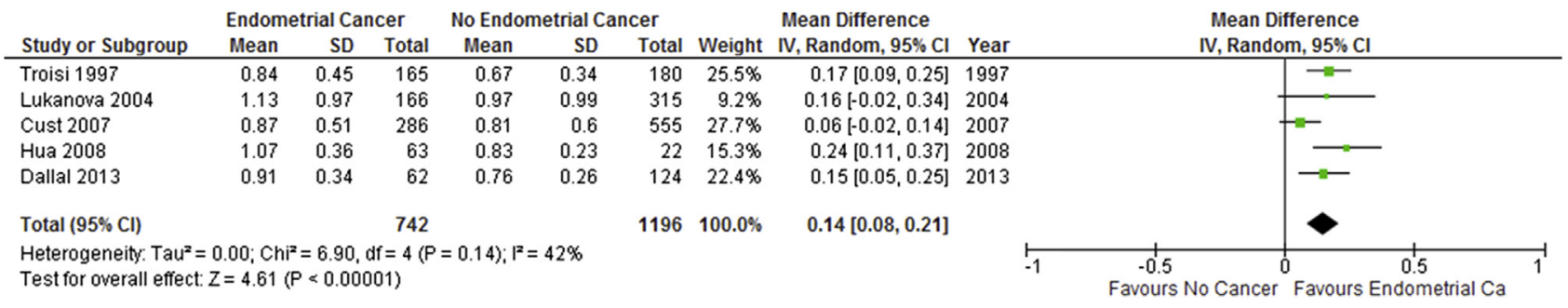

Fig. 3. Forest plot of the association between c-peptide levels and endometrial cancer.

evaluate the association of insulin resistance in EC patients based on histopathological types due to lack of data stratification by EC type in the included studies. However, both EC types share common etiologic factors
[66]. Secondly, data paucity restricted us from accounting for confounding factors such as comorbidities, anthropometry, previous hormone treatments, and lifestyle factors. In spite of this limitation,

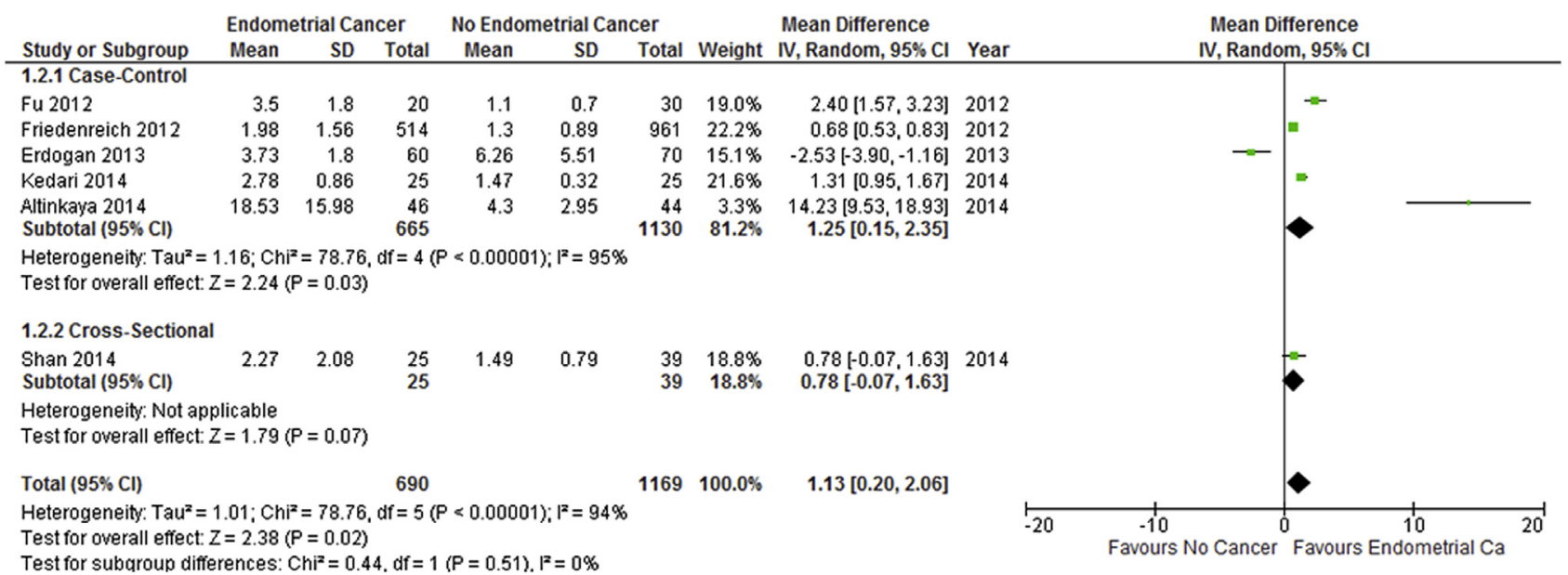

Fig. 4. Forest plot of the association between homeostatic model assessment - insulin resistance values and endometrial cancer. 
our findings have strong validity as insulin resistance plays a central role in the endometrial carcinogenic process. Hyperinsulinemia enhances the subclinical inflammation status and dysregulates sex hormone production and glycemic status. Obesity may also contribute to the hyperinsulinemia and EC risk [67]. Furthermore, abdominal adiposity plays a role in creating a proinflammatory metabolic environment which could result in both insulin resistance and cancer [68]. Well-designed studies are warranted to establish these associations. Thirdly, because of lack of data on steroid hormone levels in the studied populations, we could not assess the role of insulin-related markers versus steroid hormone status. In diabetic patients, the increased levels of oestrogen and androgen and the decreasing level of progesterone are considered potentially carcinogenic conditions for the breast, endometrium and ovaries. Hyperinsulinism also indirectly produces changes in sex hormone-binding globulin (SHBG) levels, including increases in the levels of oestrogen [69]. High BMI (and hyperadiponectinemia) and non-alcoholic fatty liver may also increase circulating SHBG $[70,71]$. In our systematic review, only Dossus et al. [36] reported the univariable association between SHBG levels and EC and there were no studies reporting fatty liver characteristics. These factors are potential contributors of insulin resistance and endometrial carcinogenesis that should be assessed in future studies. Furthermore, insulin- and steroid-related changes may act synergistically in hormone-dependent organs. In addition, hyperinsulinemia may alter the production of insulin-like growth factor-I (IGF-I), may bind to IGF-I receptors and inhibit IGF binding protein-I (IGFBP-I) and thus further contributing to carcinogenesis [72]. Only Dossus et al [36]. evaluated the univariable association between levels of IGFBP-I and -II and EC. Therefore, we could not evaluate the association between IGFBPs and EC in a formal meta-analysis. Finally, meta-analysis of observational studies can only define associations and not causes and consequences of variables.

Impaired insulin cell response is associated to increased pancreatic beta-cell insulin secretion and circulatory hyperinsulinemia. Insulin resistance is due to both genetic and lifestyle factors, and has been associated with increased risk of metabolic syndrome, cardiovascular disease, cancer, other diseases, and mortality. Diabetes mellitus is associated with increased cancer risk [73,74]. However, limited information is available in terms of insulin resistance and risk of EC. Hyperinsulinemia can increase the levels of gonadal steroids by reducing the circulating SHBG [75], although in our systematic review there were no studies with simultaneous assessment of insulin resistance and SHBG levels. The link between anthropometric variables (height and different obesity end-points) and EC has been studied [76]. It has been proposed that obesity favours a chronic systemic inflammatory status, reduces SHBG levels, and stimulates the IGF-I axis that would contribute to cancer progression [77-79]. Further welldesigned studies are needed to define how important are our findings in the context of the current knowledge of EC $[2,59,65]$, including anthropometric variables, body fat composition, biochemical markers such as IGF and IGFBPs, adipokines and endometrial genomic markers.

In conclusion, this comprehensive systematic review and meta-analysis demonstrate that higher fasting insulin, higher C-peptide and high HOMA-IR are associated with the risk of EC. Changes in lifestyle such as exercise, a healthy diet or selective nutrients may be recommended to improve insulin sensitivity and delay/ reduce the risk of EC. Furthermore, the information provided here may support future research on the prophylactic use of an insulin sensitiser, such as metformin, or other therapeutic strategies to reduce the risk of EC in high-risk populations.

\section{Contributors}

AVH, VP, and FRP-L designed the study. AVH, VP and VAB-Z did the literature searches and designed the data extraction form. VP, VAB-Z, PT and AD extracted the data. AVH cross-checked the data extraction. VAB$\mathrm{Z}$ and VP did the statistical analyses. AVH supervised the statistical analyses. FRP-L and VP wrote the paper. AVH, VP, VAB-Z, PT, AD and FRP-L critically revised subsequent drafts. All authors read and approved the submitted version.

\section{Conflict of interest statement}

AVH, VP, VAB-Z, PT, AD and FRP-L declare no relevant competing interests. $\mathrm{AD}$ has received research funding from $3 \mathrm{M}$ Incorporation.

\section{Sources of support}

None.

\section{Acknowledgments}

The authors would like to thank to Dr. Rebeca Troisi for providing additional information on C-peptide data.

\section{Appendix A. Supplementary data}

Supplementary data related to this article can be found at http://dx.doi.org/10.1016/j.ejca.2015.08.031. 


\section{References}

[1] Ashihara K, Tanaka T, Maruoka R, Ono YJ, Tanabe A, Terai Y, et al. Postmenopausal patients with endometrial cancer of type 1 have elevated serum estradiol levels in the ovarian vein. Int J Gynecol Cancer 2014;24:1455-60.

[2] Sénechal C, Cottereau E, de Pauw A, Elan C, Dagousset I, Fourchotte V, et al. Environmental and genetic risk factors for endometrial carcinoma. Bull Cancer 2015;102:256-69.

[3] Ashton KA, Proietto A, Otton G, Symonds I, McEvoy M, Attia J, et al. Polymorphisms in genes of the steroid hormone biosynthesis and metabolism pathways and endometrial cancer risk. Cancer Epidemiol 2010;34:328-37.

[4] Xu J, Lin X, Zhu H, Zhang Z, Yang B. Genetic variation of the CYP17 and susceptibility to endometrial cancer: a meta-analysis. Mol Biol Rep 2013;40:5085-91.

[5] Collaborative Group on Epidemiological Studies on Endometrial Cancer. Endometrial cancer and oral contraceptives: an individual participant meta-analysis of 27276 women with endometrial cancer from 36 epidemiological studies. Lancet Oncol 2015 Aug 4. pii: S1470-2045(15)00212-0. doi:10.1016/S1470-2045(15)00212-0. PubMed PMID: 26254030.

[6] Trabert B, Wentzensen N, Yang HP, Sherman ME, Hollenbeck AR, Park Y, et al. Is estrogen plus progestin menopausal hormone therapy safe with respect to endometrial cancer risk? Int J Cancer 2013;132:417-26.

[7] Al-Mubarak M, Tibau A, Templeton AJ, Cescon DW, Ocana A, Seruga B, et al. Extended adjuvant tamoxifen for early breast cancer: a meta-analysis. PLoS One 2014;9:e88238.

[8] Brinton LA, Westhoff CL, Scoccia B, Lamb EJ, Trabert B, Niwa S, et al. Fertility drugs and endometrial cancer risk: results from an extended follow-up of a large infertility cohort. Hum Reprod 2013;28:2813-21.

[9] Bhaskaran K, Douglas I, Forbes H, dos-Santos-Silva I, Leon DA, Smeeth L. Body-mass index and risk of 22 specific cancers: a population-based cohort study of $5 \cdot 24$ million UK adults. Lancet 2014;384:755-65.

[10] Zhang Y, Liu H, Yang S, Zhang J, Qian L, Chen X. Overweight, obesity and endometrial cancer risk: results from a systematic review and meta-analysis. Int J Biol Markers 2014;29:e21-9.

[11] Li X, Shao R. PCOS and obesity: insulin resistance might be a common etiology for the development of type I endometrial carcinoma. Am J Cancer Res 2014;4:73-9.

[12] Schmid D, Leitzmann MF. Television viewing and time spent sedentary in relation to cancer risk: a meta-analysis. J Natl Cancer Inst 2014;106. pii:dju098.

[13] Liao C, Zhang D, Mungo C, Tompkins DA, Zeidan AM. Is diabetes mellitus associated with increased incidence and diseasespecific mortality in endometrial cancer? A systematic review and meta-analysis of cohort studies. Gynecol Oncol 2014;135: 163-71.

[14] Barry JA, Azizia MM, Hardiman PJ. Risk of endometrial, ovarian and breast cancer in women with polycystic ovary syndrome: a systematic review and meta-analysis. Hum Reprod Update 2014;20:748-58.

[15] Wang T, Rohan TE, Gunter MJ, Xue X, Wactawski-Wende J, Rajpathak SN, et al. A prospective study of inflammation markers and endometrial cancer risk in postmenopausal hormone nonusers. Cancer Epidemiol Biomarkers Prev 2011;20:971-7.

[16] Izadi V, Farabad E, Azadbakht L. Serum adiponectin level and different kinds of cancer: a review of recent evidence. ISRN Oncol 2012;2012:982769.

[17] Zhang Q, Celestino J, Schmandt R, McCampbell AS, Urbauer DL, Meyer LA, et al. Chemopreventive effects of metformin on obesity-associated endometrial proliferation. Am J Obstet Gynecol 2013;209. 24.e1-12.
[18] Burzawa JK, Schmeler KM, Soliman PT, Meyer LA, Bevers MW, Pustilnik TL, et al. Prospective evaluation of insulin resistance among endometrial cancer patients. Am J Obstet Gynecol 2011; 204. 355.e1-7.

[19] Gunter MJ, Hoover DR, Yu H, Wassertheil-Smoller S, Manson JE, Li J, et al. A prospective evaluation of insulin and insulin-like growth factor-I as risk factors for endometrial cancer. Cancer Epidemiol Biomarkers Prev 2008;17:921-9.

[20] Pérez-López FR. Metformine treatment and evolution of endometrial cancer. Climacteric 2014;17:207-9.

[21] Matthews DR, Hosker JP, Rudenski AS, Naylor BA, Treacher DF, Turner RC. Homeostasis model assessment: insulin resistance and beta-cell function from fasting plasma glucose and insulin concentrations in man. Diabetologia 1985;28:412-9.

[22] Wells GA, Shea B, O'Connell D, Peterson J, Welch V, Losos M, et al. The Newcastle-Ottawa Scale (NOS) for assessing the quality of nonrandomised studies in meta-analyses. Ottawa, Canada: Ottawa Health Research Institute; 2011. Available, http://www. ohri.ca/programs/clinical_epidemiology/oxford.htm.

[23] Herzog R, Álvarez-Pasquin MJ, Díaz C, Del Barrio JL, Estrada JM, Gil Á. Are healthcare workers' intentions to vaccinate related to their knowledge, beliefs and attitudes? A systematic review. BMC Public Health 2013;13:154.

[24] Moher D, Liberati A, Tetzlaff J, Altman DG. PRISMA Group. Preferred reporting items for systematic reviews and metaanalyses: the PRISMA statement. J Clin Epidemiol 2009;62: $1006-12$.

[25] DerSimonian R, Laird N. Meta-analysis in clinical trials. Control Clin Trials 1986;7:177-88.

[26] Higgins JP, Thompson SG, Deeks JJ, Altman DG. Measuring inconsistency in meta-analyses. BMJ 2003;327:557-60.

[27] Higgins JP. Commentary: heterogeneity in meta-analysis should be expected and appropriately quantified. Int J Epidemiol 2008; 37:1158-60.

[28] Egger M, Davey Smith G, Schneider M, Minder C. Bias in metaanalysis detected by a simple, graphical test. BMJ 1997;315: 629-34.

[29] Cheng JM, Corstiaan A, Hoeks SE, van der Ent M, Jewbali LS, van Domburg RT, et al. Percutaneous left ventricular assist devices vs. intra-aortic balloon pump counterpulsation for treatment of cardiogenic shock: a meta-analysis of controlled trials. Eur Heart J 2009:30:2102-8.

[30] Hozo SP, Djulbegovic B, Hozo I. Estimating the mean and variance from the median, range, and the size of a sample. BMC Med Res Methodol 2005;5:13.

[31] Guo H, Ling W, Wang Q, Liu C, Hu Y, Xia M, et al. Effect of anthocyanin-rich extract from black rice (Oryza sativa L. indica) on hyperlipidemia and insulin resistance in fructose-fed rats. Plant Foods Hum Nutr 2007;62:1-6.

[32] Battaglia C, Mancini F, Cianciosi A, Busacchi P, Facchinetti F, Marchesini GR, et al. Vascular risk in young women with polycystic ovary and polycystic ovary syndrome. Obstet Gynecol 2008;111:385-95.

[33] Review Manager (RevMan) [Computer program]. Version 5.1. Copenhagen: The Nordic Cochrane Centre, The Cochrane Collaboration; 2011.

[34] Lucas WE, Yen SSC. A study of endocrine and metabolic variables in postmenopausal women with endometrial carcinoma. Am J Obstet Gynecol 1979;134:180-5.

[35] Anderson KE, Anderson E, Mink PJ, Hong CP, Kushi LH, Sellers TA, et al. Diabetes and endometrial cancer in the Iowas Womeńs Health Study. Cancer Epidemiol Biomarkers Prev 2001; 10:611-6.

[36] Dossus L, Lukanova A, Rinaldi S, Allen N, Cust AE, Becker S, et al. Hormonal, metabolic, and inflammatory profiles and endometrial cancer risk within the EPIC cohort-A factor analysis. Am J Epidemiol 2013;177:787-99. 
[37] Nagamani M, Stuart CA, Dunhardt PA, Doherty MG. Specific binding sites for insulin and insulin-like growth factor I in human endometrial cancer. Am J Obstet Gynecol 1991;165:1865-71.

[38] Rutanen EM, Stenman S, Blum W, Karkkainen T, Lehtovirta P, Stenman UH. Relationship between carbohydrate metabolism and serum insulin-like growth factor system in postmenopausal women: comparison of endometrial cancer patients with healthy controls. J Clin Endocrinol Metab 1993;77:199-204.

[39] Gamayunova VB, Bobrov YF, Tsyrlina EV, Evtushenko TP, Berstein LM. Comparative study of blood insulin levels in breast and endometrial cancer patients. Neoplasma 1997;44:123-6.

[40] Troisi R, Potischman N, Hoover RN, Siiteri P, Brinton LA. Insulin and endometrial cancer. Am J Epidemiol 1997;146:476-82.

[41] Waksmański B, Dudkiewicz J, Dabrowski S. Function of insulinlike growth factor (IGF-I) and its binding protein (IGFBP-1) in pathological proliferation of endometrium. Wiad Lek 2001;54: 656-61.

[42] Weiderpass E, Brismar K, Bellocco R, Vainio H, Kaaks R. Serum levels of insulin-like growth factor-I, IGF-binding protein 1 and 3 , and insulin and endometrial cancer risk. Br J Cancer 2003;89: 1697-704.

[43] Lukanova A, Zeleniuch-Jacquotte A, Lundin E, Micheli A, Arslan AA, Rinaldi S, et al. Prediagnostic levels of C-peptide, IGF-I, IGFBP -1, -2 and -3 and risk of endometrial cancer. Int J Cancer 2004; 108:262-8.

[44] Cust AE, Allen NE, Rinaldi S, Dossus L, Friedenreich C, Olsen A, et al. Serum levels of C-peptide, IGFBP-1 and IGFBP-2 and endometrial cancer risk; results from the European prospective investigation into cancer and nutrition. Int J Cancer 2007;120: 2656-64.

[45] Hua SF, Xue FX, Zhang LZ, Zhao J. Expression and activation of insulin receptor substrate-1 in endometrial carcinoma. Chin J Obstet Gynecol 2008;43:437-41.

[46] Friedenreich CM, Biel RK, Lau DC, Csizmadi I, Courneya KS, Magliocco AM, et al. Case-control study of the metabolic syndrome and metabolic risk factors for endometrial cancer. Cancer Epidemiol Biomarkers Prev 2011;20:2384-95.

[47] Friedenreich CM, Langley AR, Speidel TP, Lau DC, Courneya KS, Csizmadi I, et al. Case-control study of markers of insulin resistance and endometrial cancer risk. Endocr Relat Cancer 2012;19:785-92.

[48] Modesitt SC, Geffel DL, Via J, L Weltman A. Morbidly obese women with and without endometrial cancer: are there differences in measured physical fitness, body composition, or hormones? Gynecol Oncol 2012;124:431-6.

[49] Fu JR, Lu LN, Yu LP, Wang DY, Ding KS. Serum changes of adiponectin, insulin resistance and their correlation in endometrial cancer patients. Chin J Obstet Gynecol 2012;47:672-5.

[50] Dallal CM, Brinton LA, Bauer DC, Buist DS, Cauley JA, Hue TF, et al. B FIT Research Group. Obesity-related hormones and endometrial cancer among postmenopausal women: a nested case-control study within the B FIT cohort. Endocr Relat Cancer 2013;20:151-60.

[51] Ma Y, Liu Z, Zhang Y, Lu B. Serum leptin, adiponectin and endometrial cancer risk in Chinese women. J Gynecol Oncol 2013; 24:336-41.

[52] Zhan Y, Wang J, Ma Y, Liu Z, Xu H, Lu S, et al. Serum insulinlike, growth factor binding protein-related protein 1 (IGFBP-rP1) and endometrial cancer risk in Chinese women. Int J Cancer 2013; 132:411-6.

[53] Altinkaya SO, Nergiz S, Küçük M, Yüksel H. Apelin levels are higher in obese patients with endometrial cancer. J Obstet Gynaecol Res 2015;41:294-300.

[54] Kedari GSR. Evaluation of hyperinsulinemia, inflammation and lipid profile in patients with endometrial cancer. Int J Pharm Bio Sci 2014;5:238-44.

[55] Erdogan S, Sezer S, Baser E, Gun-Eryilmaz O, Gungor T, Uysal S, et al. Evaluating vaspin and adiponectin in postmenopausal women with endometrial cancer. Endocr Relat Cancer 2013;20:669-75.

[56] Shan W, Ning C, Luo X, Zhou Q, Gu C, Zhang Z, et al. Hyperinsulinemia is associated with endometrial hyperplasia and disordered proliferative endometrium: a prospective crosssectional study. Gynecol Oncol 2014;132:606-10.

[57] Bishop EA, Lightfoot S, Thavathiru E, Benbrook DM. Insulin exerts direct effects on carcinogenic transformation of human endometrial organotypic cultures. Cancer Invest 2014;32:63-70.

[58] Esposito K, Chiodini P, Capuano A, Bellastella G, Maiorino MI, Giugliano D. Metabolic syndrome and endometrial cancer: a meta-analysis. Endocrine 2014;45:28-36.

[59] Arcidiacono B, Iiritano S, Nocera A, Possidente K, Nevolo MT, Ventura $\mathrm{V}$, et al. Insulin resistance and cancer risk: an overview of the pathogenetic mechanisms. Exp Diabetes Res 2012;2012: 789174.

[60] Zhang M, Li X, Zhang X, Yang Y, Feng Z, Liu X. Association of serum hemoglobin Alc, C-peptide and insulin-like growth factor1 levels with the occurrence and development of lung cancer. Mol Clin Oncol 2014;2:506-8.

[61] Melles E, Jornvall H, Tryggvason S, Danielsson KG, Ekberg K, Tryggvason K, et al. Degradation of proinsulin C-peptide in kidney and placenta extracts by a specific endoprotease activity. Cell Mol Life Sci 2004;61:2979-82.

[62] Tura A, Ludvik B, Nolan JJ, Pacini G, Thomaseth K. Insulin and $\mathrm{C}$-peptide secretion and kinetics in humans: direct and modelbased measurements during OGTT. Am J Physiol Endocrinol Metab 2001;281:E966-74.

[63] Kitahara CM, Trabert B, Katki HA, Chaturvedi AK, Kemp TJ, Pinto LA, et al. Body mass index, physical activity, and serum markers of inflammation, immunity, and insulin resistance. Cancer Epidemiol Biomarkers Prev 2014;23:2840-9.

[64] Singh B, Saxena A. Surrogate markers of insulin resistance: a review. World J Diabetes 2010;1:36-47.

[65] Murali R, Soslow RA, Weigelt B. Classification of endometrial carcinoma: more than two types. Lancet Oncol 2014;15:e268-78.

[66] Setiawan VW, Yang HP, Pike MC, McCann SE, Yu H, Xiang YB, et al. Type I and II endometrial cancers: have they different risk factors? J Clin Oncol 2013:31:2607-18.

[67] Garg SK, Maurer H, Reed K, Selagamsetty R. Diabetes and cancer: two diseases with obesity as a common risk factor. Diabetes Obes Metab 2014;16:97-110.

[68] Schmandt RE, Iglesias DA, Co NN, Lu KH. Understanding obesity and endometrial cancer risk: opportunities for prevention. Am J Obstet Gynecol 2011;205:518-25.

[69] Rosato V, Zucchetto A, Bosetti C, Dal Maso L, Montella M, Pelucchi $\mathrm{C}$, et al. Metabolic syndrome and endometrial cancer risk. Ann Oncol 2011;22:884-9.

[70] Simó R, Saez-Lopez C, Lecube A, Hernandez C, Fort JM, Selva DM. Adiponectin upregulates SHBG production: molecular mechanisms and potential implications. Endocrinology 2014;155: 2820-30.

[71] Simó R, Sáez-López C, Barbosa-Desongles A, Hernández C, Selva DM. Novel insights in SHBG regulation and clinical implications. Trends Endocrinol Metab 2015;26:376-83.

[72] $\mathrm{Mu} \mathrm{N}$, Zhu Y, Wang Y, Zhang H, Xue F. Insulin resistance: a significant risk factor of endometrial cancer. Gynecol Oncol 2012; 125:751-7.

[73] Giovannucci E, Harlan DM, Archer MC, Bergenstal RM, Gapstur SM, Habel LA, et al. Diabetes and cancer: a consensus report. CA Cancer J Clin 2010;60:207-21.

[74] Gristina V, Cupri MG, Torchio M, Mezzogori C, Cacciabue L, Danova M. Diabetes and cancer: A critical appraisal of the pathogenetic and therapeutic links. Biomed Rep 2015;3:131-6.

[75] Allen NE, Key TJ, Dossus L, Rinaldi S, Cust A, Lukanova A, et al. Endogenous sex hormones and endometrial cancer risk in women in the European Prospective Investigation into Cancer and Nutrition (EPIC). Endocr Relat Cancer 2008:15:485-97. 
[76] Aune D, Navarro Rosenblatt DA, Chan DS, Vingeliene S, Abar L, Vieira AR, et al. Anthropometric factors and endometrial cancer risk: a systematic review and dose-response metaanalysis of prospective studies. Ann Oncol 2015;26:1635-48.

[77] Cohen DH, LeRoith D. Obesity, type 2 diabetes, and cancer: the insulin and IGF connection. Endocr Relat Cancer 2012;19: F27-45.
[78] Doyle SL, Donohoe CL, Lysaght J, Reynolds JV. Visceral obesity, metabolic syndrome, insulin resistance and cancer. Proc Nutr Soc 2012;71:181-9.

[79] Simó R, Barbosa-Desongles A, Lecube A, Hernandez C, Selva DM. Potential role of tumor necrosis factor- $\alpha$ in downregulating sex hormone-binding globulin. Diabetes 2012;61: $372-82$. 